\title{
Forecasting Model of Production and Price of Grains Commodity in Central Sulawesi
}

\author{
Muhardi $^{1 *}$, Dizzi Evansyah ${ }^{2}$, Made Antara $^{2}$, Effendy $^{2}$ \\ ${ }^{1}$ Department of Agrotechnology, Agriculture Faculty of Tadulako University, Palu, Indonesia \\ ${ }^{2}$ Department of Agriculture Economics, Agriculture Faculty of Tadulako University, Palu, Indonesia \\ *muhardi_hasanuddin@yahoo.com
}

Received: January 22, 2021. Revised: April 7, 2021. Accepted: April 9, 2021. Published: April 16, 2021.

\begin{abstract}
Food derives from biological resources, animals, and water, whether processed or not processed, meant as food or drink for human consumption. Food commodities have often been referred to as staples or basic needs of Indonesian people and others. The availability of staples has played a strategic role in stabilizing food security, economic security, and national political stability, leading to the issue of availability of staples receiving very serious attention from the Indonesia government. This study analyzed the best model of production forecasting and prices of rice and corn in Central Sulawesi, Indonesia. The study used the ARIMA method to predict the production and prices of rice and corn. The results of the analysis showed that the best model was the forecasting model of ARIMA rice production $(4,0,0)$ with decreasing production forecast data trends and corn with the ARIMA model $(1,0,0)$ with increasing production forecast data trends. The forecasting model of ARIMA rice price $(2,2,0)$ with decreasing price forecast data trends and ARIMA corn prices $(2,2,0)$ with increasing price forecast data trends.
\end{abstract}

\section{Key-Words: - Forecasting, Grains, Rice, Corn}

\section{INTRODUCTION}

Agriculture is an economic sector in Indonesia, both micro and macro. At the micro-level, agriculture provides the livelihood of the majority of the rural population, and at the macro-level it supports the manufacturing industry and ensures national food security. Food, by definition, is everything that comes from biological resources, animals, and water, whether processed or not processed, which is intended as food or drink for human consumption $[1,2]$. Included in the definition of food are food additives, food raw materials, and other materials used in the process of preparing, processing, and/or making food and drink.

Food security is a condition of fulfillment of food needs - in this case, for all the Indonesian people. This has been reflected in the availability of sufficient food, both in quantity and quality, and affordable by people's purchasing power. Food commodities have often been referred to as staples or basic needs of Indonesian people. The availability of staples has played a strategic role in stabilizing food security, economic security, and national political stability, leading to the availability of staples receiving substantial attention from the government [3]. So far, there has been accurate and comprehensive information about the amount of staples consumption in Indonesia. Several calculation approaches of staples consumption based on various sources have indicated very diverse information. The national socio-economic survey as one of the information sources of staples consumption, though it has only been able to accurately capture processed staples consumption inside the household, while staples consumption of those processed outside the household has not yet been calculated accurately [4].

Staples are food materials that can be processed into food. The survey results of the Central Statistics Agency of Central Sulawesi showed that the most consumed staples were grains. The average consumption of the grains food group is 995,446 calories per capita per day [5]. The most consumed grains in the region were rice and corn [5].

Grains are sold freely in the market to meet their daily needs. Fulfillment of the need for grains has been one of the most important objectives both at the national and individual scales. Imbalance of production and community needs for grains has caused unstable prices, while price instability made this need difficult to fulfill. 
Price instability could complicate in planning of production and investment activities. Stable prices could support the maintenance of people's purchasing power $[6,7]$. In the case of price instability, producers and consumers needed information of production forecasting and grain prices, allowing business people to carefully plan their business ventures $[8,9]$.

Production forecasting and price of grains with time-series data could be done using a statistical method derived from a multiple linear regression model $[10,11]$, but forecasting results have not been accurate $[12,13]$. One of the statistical methods for analyzing time-series data is the Autoregressive Integrated Moving Average (ARIMA). The advantage of this method is that it only used past and present values of the dependent variable to produce forecasting [14-16]. This study analyzed the forecasting model of production and the prices of rice and corn commodities in Central Sulawesi, Indonesia.

\section{Study MethodS}

A. Location And Data Sources

This study was conducted in Central Sulawesi in January of 2020. The study used time-series data from 2015 to 2019 . The variables collected were rice and corn production and rice and corn prices. Sources of data came from the Department of Industry and Trade and the Department of Food Crops and Horticulture in Central Sulawesi. Forecasting of production and prices used the ARIMA Box Jenkins Method.

\section{B. Determination of the Forecasting Model of production and price of grains}

Table 1 exhibits the regression equation of forecasting of production and price of grains.

Table 1. Equation of forecasting of production and price of grains in Central Sulawesi

\begin{tabular}{|c|c|c|}
\hline Variable & $\begin{array}{l}\text { Autoregressive Model } \\
\text { (AR) }\end{array}$ & $\begin{array}{l}\text { Moving Average Model } \\
\text { (MA) }\end{array}$ \\
\hline $\begin{array}{l}\text { Rice } \\
\text { production }\end{array}$ & $\begin{array}{l}Y_{1 t}=a+a_{1} Y_{t-1}+\ldots+ \\
a_{i} Y_{t-I}+e_{t}\end{array}$ & $\begin{array}{l}Y_{1 t}=e_{t}-Y_{1} e_{t-1}-Y_{1} e_{t-2}- \\
\ldots Y_{n} e_{t-n}\end{array}$ \\
\hline Rice price & $\begin{array}{l}Y_{2 t}=a+a_{1} Y_{t-1}+\ldots+ \\
a_{i} Y_{t-I}+e_{t}\end{array}$ & $\begin{array}{l}Y_{2 t}=e_{t}-Y_{1} e_{t-1}-Y_{1} e_{t-2}- \\
\ldots Y_{n} e_{t-n}\end{array}$ \\
\hline $\begin{array}{l}\text { Corn } \\
\text { production }\end{array}$ & $\begin{array}{l}Y_{3 t}=a+a_{1} Y_{t-1}+\ldots+ \\
a_{i} Y_{t-1}+e_{t}\end{array}$ & $\begin{array}{l}Y_{3 t}=e_{t}-Y_{1} e_{t-1}-Y_{1} e_{t-2}- \\
\ldots Y_{n} e_{t-n}\end{array}$ \\
\hline Corn Price & $\begin{array}{l}Y_{4 t}=a+a_{1} Y_{t-1}+\ldots+ \\
a_{i} Y_{t-1}+e_{t}\end{array}$ & $\begin{array}{l}Y_{4 t}=e_{t}-Y_{1} e_{t-1}-Y_{1} e_{t-2}- \\
\ldots Y_{n} e_{t-n}\end{array}$ \\
\hline
\end{tabular}

Note: $a-a_{i}=$ AR coefficient, $Y_{1}-Y_{n}=M A$ coefficient

The best forecasting model of production and price of grains was selected based on the adjusted $\mathrm{R} 2$ value criteria, Akaike information criteria (AIC), and Schwarz information criteria (SIC). If the model met more than one of these requirements, it was chosen again based on the value of the Root Mean
Square Error (RMSE) [17, 18]. The model with the smallest RMSE value was the most suitable model for forecasting. The combination of Autoregressive (p) and Moving average (q) formed the ARIMA model ( $p, d, q)$ where $p$ was the AR order, $q$ was the MA order, and $d$ was the number of differences to obtain data that was stationary to the average. An important requirement for modeling data on the ARIMA time-series method was the data stationarity.

The current study processed production data and grain prices using the Eviews application version 9. The study used the best forecasting model to predict the value of production and price of grains for the period of January to December 2020.

\section{RESULTS AND DISCUSSION}

Table 2 exhibits the analysis results of the best forecasting model of production and price of rice and corn. The model can predict the production and price of rice and corn for January to December 2020.

Table 2. The best forecasting models of production and price of rice and corn in Central Sulawesi

\begin{tabular}{lcc}
\hline production and price & Variable & $\begin{array}{c}\text { ARIMA } \\
\text { Model } \\
(\mathbf{p}, \mathbf{d}, \mathbf{q})\end{array}$ \\
\hline Rice production & $\mathrm{Y}_{1}$ & $(4,0,0)$ \\
Rice price & $\mathrm{Y}_{2}$ & $(2,2,0)$ \\
Corn production & $\mathrm{Y}_{3}$ & $(1,0,0)$ \\
Corn Price & $\mathrm{Y}_{4}$ & $(2,2,0)$ \\
\hline
\end{tabular}

A. Rice Production Forecasting in Central Sulawesi Table 3 lists the results of rice production forecasting.

Table 3. Rice Production Forecasting from January to December 2020 in Central Sulawesi

\begin{tabular}{lc}
\hline Month & $\begin{array}{c}\text { Rice Production } \\
\text { Forecast (ton) }\end{array}$ \\
\hline January & 37,137 \\
February & 36,143 \\
March & 35,077 \\
April & 33,938 \\
May & 32,727 \\
June & 31,443 \\
July & 30,087 \\
August & 28,657 \\
September & 27,156 \\
October & 25,582 \\
November & 23,935 \\
December & 22,215 \\
\hline
\end{tabular}


Table 3 reveals the results of the rice production forecast for 2020 with the ARIMA method, which indicated a decrease in production. This happened because of the reduced size of the rice field planting area, as well as a decrease in the productivity of cultivated land. Other factors included pest attack and disease, natural disasters (floods), and the sustainable dry season. The decrease in production would be exacerbated by the ongoing COVID-19 pandemic that has hit Central Sulawesi. The decrease in production would impact the consumption needs of the population of Central Sulawesi - needs that are increasing every year. Increasing rice production could be done by increasing cultivated land area using superior varieties that are resistant to disease pests and high productivity, at the same time using balanced fertilizers, adequate irrigation, improving planting methods, enhancing mechanization and practicing soil maintenance [19-22].

\section{B. Rice Price Forecasting in Central Sulawesi}

Table 4 lists the results of rice price forecasting.

Table 4. Rice Price Forecasting from January to December 2020 in Central Sulawesi

\begin{tabular}{lr}
\hline Month & $\begin{array}{c}\text { Rice Price Forecast } \\
\text { (IDR) }\end{array}$ \\
\hline January & 10,153 \\
February & 10,106 \\
March & 10,041 \\
April & 9,965 \\
May & 9,883 \\
June & 9,791 \\
July & 9,687 \\
August & 9,575 \\
September & 9,452 \\
October & 9,320 \\
November & 9,178 \\
December & 9,026 \\
\hline
\end{tabular}

Table 4 illustrates the rice price forecasting in 2020, where the price of rice has decreased monthly in the first several months of the year. This forecast is contrary to the economic rule that dictates how if production decreases, selling price will increase. This happened because the rice stock in the Indonesian Bureau of Logistics fulfilled the consumption needs of the people of Central Sulawesi, ensuring there was no imbalance between demand and supply. Moreover, there is often government interference with the price of rice in Indonesia. This result differs from the findings of
Abbasi et al. [23] in Pakistan where an increase in rice production also heightened

C. Corn Production Forecasting in Central Sulawesi Table 5 lists the results of corn production forecasting.

Table 5. Results of Corn Production Forecasting from January to December 2020 in Central Sulawesi

\begin{tabular}{lc}
\hline Month & $\begin{array}{c}\text { Corn Production } \\
\text { Forecast (ton) }\end{array}$ \\
\hline January & $30,686.90$ \\
February & $30,581.10$ \\
March & $30,786.50$ \\
April & $30,981.50$ \\
May & $31,166.20$ \\
June & $31,340.40$ \\
July & $31,504.30$ \\
August & $31,657.80$ \\
September & $31,800.90$ \\
October & $31,933.70$ \\
November & $32,056.00$ \\
December & $32,168.00$ \\
\hline
\end{tabular}

Table 5 shows that the corn production forecast increases monthly. This happened because the productivity of corn agricultural land remained relatively productive for planting corn. According to Badar et al. [20], yields of wheat, rice, and corn increase when planting techniques improve. Indeed, the tropical climate in Central Sulawesi strongly supports the growth of corn [24].

D. Corn Price Forecasting in Central Sulawesi

The results of Corn Price Forecasting are listed in Table 6.

Table 6. Results of Corn Price Forecasting from January to December 2020 in Central Sulawesi

\begin{tabular}{lc}
\hline \multicolumn{1}{c}{ Month } & $\begin{array}{c}\text { Corn Price } \\
\text { Forecast (IDR) }\end{array}$ \\
\hline January & $8,039.51$ \\
February & $8,089.44$ \\
March & $8,142.10$ \\
April & $8,195.49$ \\
May & $8,249.07$ \\
June & $8,302.70$ \\
July & $8,356.35$ \\
August & $8,409.99$ \\
September & $8,463.64$ \\
October & $8,517.29$ \\
November & $8,570.94$ \\
December & $8,624.59$ \\
\hline
\end{tabular}

Table 6 shows the price of corn and how it tended to increase. This happened because the consumption and use of corn as animal feed was imbalanced with corn production. In addition, there 
were corn products derived from Central Sulawesi that sold outside the region for animal feed needs. Central Sulawesi needed to expand its agricultural land being used for corn, thereby balancing production and consumption so that the price of corn would be stable $[25,26]$.

\section{CONCLUSION}

The best forecasting model for grain commodities in Central Sulawesi was that of ARIMA rice production $(4,0,0)$ with decreasing production forecast data trends, and ARIMA corn $(1,0,0)$ with increasing production forecast data trends. The forecasting model of ARIMA rice prices $(2,2,0)$ saw decreasing price forecast data trends and ARIMA corn prices $(2,2,0)$ saw increasing price forecast data trends. This meeting can be a reference in making decisions, especially in making policies related to the production and price of rice and corn in Central Sulawesi. This finding could be a reference when it comes to making decisions, especially in developing policies related to the production and price of rice and corn in Central Sulawesi.

\section{REFERENCES:}

[1] Jones JM, Regulatory Aspects of Whole Grain and Whole Grain Foods: Definitions and Labeling, Cereal Chemistry; St. Paul, Vol. 87, No. 2, 2010, pp. 150-154.

[2] Thompson C, Smith D. and Cummins S, Food banking and emergency food aid: expanding the definition of local food environments and systems, International Journal of Behavioral Nutrition and Physical Activity, Vol. 16, No. 2, 2019, pp. https://doi.org/10.1186/s12966-0180765-2

[3] Renwick K and Powell LJ, Focusing on the Literacy in Food Literacy: Practice, Community, and Food Sovereignty, Journal of Family and Consumer Sciences; Alexandria, Vol. 111, No. 1, 2019, pp 24-30.

[4] BPS Indonesia, Survei Konsumsi Bahan Pokok. Badan Pusat Statistik (BPS) Indonesia, 2015 https://sirusa.bps.go.id/index.php?r=sd/view\&k $\mathrm{d}=3408 \&$ th $=2015$

[5] BPS, Sulawesi Tengah Dalam Angka. Badan Pusat Statistik (BPS) Provinsi Sulaesi Tengah, 2018.

[6] Ahmed DA, Abdelsalam, M A M, Inflation Instability Impact on Interest Rate in Egypt: Augmented Fisher Hypothesis Test, Applied Economics and Finance, Vol. 5, No. 1, 2017, pp. https://doi.org/10.11114/aef.v5i1.2709
[7] Hedenstierna G, Unstable Inflation Is Harmful and More Common Supine Than Prone. American Journal of Respiratory and Critical Care Medicine, Vol. 198, No. 2, 2018, pp.146147.

[8] Arlt J, Arltova M, Forecasting of the Annual Inflation Rate in the Unstable Economic Conditions. International Conference on Mathematics and Computers in Sciences and in Industry (MCSI), 2015, pp.231-234. https://doi.org/10.1109/MCSI.2015.34

[9] Lidiema C, Modelling and Forecasting Inflation Rate in Kenya Using SARIMA and Holt-Winters Triple Exponential Smoothing, American Journal of Theoretical and Applied Statistics, Vol. 6, No. 3, 2017, pp. $161 . \quad$ https://doi.org/10.11648/j. ajtas.20170603.15

[10] Komontree P, Tongkumchum P, Karntanut W, Trends in marine fish catches at Pattani Fishery Port (1999-2003). Songklanakarin Journal of Science and Technology, Vol. 28, No. 4, 2006, pp. 887-895.

[11] Chesoh S, Lim A, Forecasting fish catches in the Songkhla Lake basin, ScienceAsia, Vol. 34, 2008, pp. 335-340.

[12] Aasim, Singh SN, Mohapatra A, Repeated Wavelet Transform Based ARIMA Model for Very Short-term Wind Speed Forecasting, Renewable Energy, Vol. 136, 2019, pp. 758768.

[13] Mills TC, ARIMA Models for Nonstationary Time Series, In Applied Time Series Analysis, 2019, pp.57-69.

[14] Khashei M, Bijari M, Raissi Ardali GA, Hybridization of Autoregressive Integrated Moving Average (ARIMA) with Probabilistic Neural Networks (PNNs), Computers \& Industrial Engineering, Vol. 63, No. 1, 2012, pp. 37-45.

[15] Naranjo L, Plaza F, Yanez E, Barbieri MA, Sanchez F, Forecasting of jack mackerel landings (Trachurus murphyi) in centralsouthern Chile through neural networks, Fisheries Oceanography, Vol. 24, 2015, pp. 219-228.

[16] Yuan C, Liu S, Fang Z, Comparison of China's Primary Energy Consumption Forecasting by using ARIMA (The Autoregressive Integrated Moving Average) Model and $\operatorname{GM}(1,1)$ Model, Energy, Vol. 100, 2016, pp. 384-390. https://doi.org/10.1016/j. energy.2016.02.001.

[17] Hong T, Kim C-J, Jeong J, Kim J, Koo C, Jeong K, Lee M, Framework for Approaching the Minimum CV (RMSE) using Energy 
Simulation and Optimization Tool, Energy Procedia, Vol. 88, 2016, pp. 265-270.

[18] Mentaschi L, Besio G, Cassola F, Mazzino A, Problems in RMSE-based wave model validations, Ocean Modelling, Vol. 72, 2013, pp. 53-58.

[19] Naohisa K, Robertson AW, Ines AVM, Qian JH, DeWitt DG, Lucero A, Prediction of Rice Production in the Philippines Using Seasonal Climate Forecasts, Journal of Applied Meteorology and Climatology ; Boston, Vol. 52, No. 3, 2013, pp. 552-569.

[20] Badar N, Fatima H, Jabbar A, Asif M, Major Food Crops Production And Yield Forecast In Pakistan, Pakistan J. Agric. Res., Vol. 28, No. 3, 2015, pp. 295-303.

[21] Zahra N, Akmal N, Naheed S, Habib N, Siddiqui S, Raza I, Trend analysis of rice area and yield in Punjab, Pakistan J. Agric. Res. Vol. 28, No. 4, 2015, pp. 439-444.

[22] Antara M, Effendy, Allocation optimization of farmers' resources to achieve maximum income in Parigi Moutong Regency, Asian J. Sci. Res., Vol. 11, 2018, pp. 267-275.

[23] Abbasi SS, Tahir A, Raza I, Abid S, Khan MN, Trend analysis and forecasting of wheat and rice prices in Pakistan, Pakistan J. Agric. Res., Vol. 28, No. 3, 2015, pp. 310-317.

[24] Mathieu JA, Aires F, Statistical WeatherImpact Models: An Application of Neural Networks and Mixed Effects for Corn Production over the United States, American Meteorological Society, Vol. 55, 2016, pp. 2509-2527.

[25] García-Salazar JA, Skaggs RK, Crawford TL, World price, exchange rate and inventory impacts on the mexican corn sector: a case study of market volatility and vulnerability, Interciencia; Caracas, Vol. 37, No. 7, 2012, pp. 498-505.

[26] Dutta A, Bouri E, Junttila J, Uddin GS, Does corn market uncertainty impact the US ethanol prices? Global Change Biology, Bioenergy; Oxford, Vol. 10, No. 9, 2018, pp. 683-693. DOI:10.1111/gcbb.12527

\section{Creative Commons Attribution License 4.0 (Attribution 4.0 International , CC BY 4.0)}

This article is published under the terms of the Creative Commons Attribution License 4.0 https://creativecommons.org/licenses/by/4.0/deed.en US 